\title{
THE MEANING OF WORK SAGA: A COLLECTIVE JOB CRAFTING EXPERIENCE
}

\author{
NEWTON C. M. DE MELO \\ (iD) https://orcid.org/0000-0002-3547-5394 \\ DÉBORA C. P. DOURADO ${ }^{1}$ \\ (iD) https://orcid.org/0000-0001-8316-8551
}

To cite this paper: Melo, N. C. M., \& Dourado, D. C. P. (2018). The meaning of work saga: A collective job crafting experience. Revista de Administração Mackenzie, 19(spe). doi:10.1590/16786971/eRAMD180077

Submission: Apr. 30, 2018. Acceptance: July 16, 2018.

Universidade Federal de Pernambuco (UFPE), Recife, PE, Brazil.

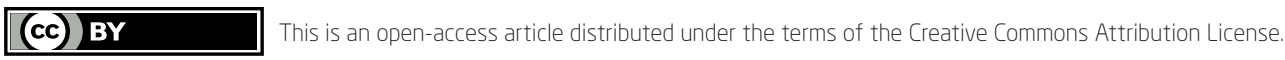

\footnotetext{
This paper may be copied, distributed, displayed, transmitted or adapted if provided, in a clear and explicit way, the name of the journal, the edition, the year and the pages on which the paper was originally published, but not suggesting that RAM endorses paper reuse. This licensing term should be made explicit in cases of reuse or distribution to third parties. It is not allowed the use for commercial purposes.

Este artigo pode ser copiado, distribuído, exibido, transmitido ou adaptado desde que citados, de forma clara e explícita, o nome da revista, a edição, o ano e as páginas nas quais o artigo foi publicado originalmente, mas sem sugerir que a RAM endosse a reutilização do artigo. Esse termo de licenciamento deve ser explicitado para os casos de reutilização ou distribuição para terceiros. Não é permitido o uso para fins comerciais.
} 


\section{ABSTRACT}

Purpose: Our main purpose was to explore how collective job crafting relates to the meaning of work and the meaning-making processes.

Originality/value: We explored the job crafting model to study the meaning of work at the collective level. But, while most job crafting studies focus on the relation between workers and tasks, we focused on the collective meaning-making that emerges from workers actively adapting tasks, significance, and relationships in their jobs. As for the practitioners, we alert for a possible trapdoor through which job crafting can fall back into plain hierarchical job design if it is not actively and autonomously engaged by workers.

Design/methodology/approach: We used basic qualitative research to combine interpretative analysis (aligned with our topic and theoretical model) and the possibility to look into an interaction scenario (aligned with our objectives). Data was collected though informants' responses to a semi-structured interview and analyzed using content analysis.

Findings: We found out that workers shared an understanding of the problems of work meanings and engage in a quest to make sense of their work lives both 1 . At the organizational level - arranging work in unorthodox ways -; and 2. At the interpersonal level - adhering to specific roles to attach meaning to work. Our findings shed light on new aspects of the job crafting model, particularly, on the meaning of work centrality to the model in collective job crafting experiences.

\section{KEYWORDS}

Meaning of work. Meaningful work. Work arrangements. Management of meaning. Collective job crafting. 


\section{INTRODUCTION}

Workers and organizations are getting divorced. People expect their work to meet subjective needs, to their certain meanings, but as in any marriage, they may feel betrayed when organizations fail to fulfill these functions. The process of attaching meaning to work seems to unfold on multiple dimensions. On a more subjective side, it may include both individual aspirations and collective matters such as work relations and mutual trust.

On the other hand, taking a more concrete stance, it may relate to the specific tasks performed and to the work arrangements in which these tasks are determined and distributed. Some authors, moving across the far critical side of the theoretical terrain, go up to the point of considering capitalist work arrangements completely incompatible with meaningful work (e.g., Antunes, 2009; Braverman, 1998; Dejours, 1992). Problems regarding the meaning of the work domain may cause the meaning attachment process to shatter, spilling dissonant meanings of work through organizational cracks and growing people apart. In the absence of shared meanings, many forms of pretending arise such as cynicism (Cartwright \& Holmes, 2006) or existential labor (Bailey, Madden, Alfes, Shantz, \& Soane, 2017). This controversial scenario demands a completely new social contract at work (Kochan, 2016).

The administration has been attempting such social contracts at work by emphasizing the management of meanings. That is, making the subjective life of workers more controllable (e.g., Busse, Kwon, Kloep, Ghosh, \& Warner, 2018; Cleavenger \& Munyon, 2013). This kind of move is hardly new and reaches both practitioners and scholars. In fact, since the Hawthorne experiments, subjective variables have been introduced to studies and theories not only to understand but also to control workers' subjective lives and behaviors (Braverman, 1998). What this kind of research does, then, turns knowledge about the meaning of work into prescriptions for increasing productivity (Lips-Wiersma \& Morris, 2009). In other words, these theories and the practices they inform are essentially heteronomous. But what does this entail?

Trying to motivate and commit workers by feeding them scientifically calculated meanings do not ease frustration from meaningless work arrangements and from insincere rapport among colleagues. When it comes to working meanings, people can immediately detect lack of authenticity, implying that meaning should regain its proper place taken by instrumental 
management theories, for it cannot be provided, but it should surface from real, meaningful interactions and aspirations (Lips-Wiersma \& Morris, 2009).

Also, when organizations cannot provide real meaningful workplaces, people may depart from the spontaneous meaning-making process (Bailey et al., 2017; Cartwright \& Holmes, 2006). Those under the management of meaning techniques may feel constrained to play certain roles and espouse certain representations which they feel might put them in some advantageous position. For example, job applicants or seasoned employees aspiring to promotion may engage in impression management practices regarding work meanings to appear suitable for a position. Managers could adopt some discourses to set an example of commitment to their teams. Owners could advertise a meaningful workplace image to attract more qualified candidates. Each player makes assumptions about what others expect and broadcast their work meanings and identities accordingly. As meanings are constructed through interactions (Rodrigues, Morin, \& Strehlau, 2009), all this role-playing and endorsements may combine to produce an unauthentic business culture.

We propose that any new social contract at work must take into account the meanings attached to work - contents, and evaluations about jobs, roles and self-meanings (Wrzesniewski, Dutton, \& Debebe, 2003) - and also the processes people use to build and share those meanings. More importantly, we should delve into processes that grant people more autonomous choices regarding the matter. We believe that a promising road for an authentic and fair social bargain could rise from the particularly insightful model of job crafting proposed by Wrzesniewski and Dutton (2001). Conversely to the prescriptive, heteronomous models, job crafting conceptualizes how people actively adapt the tasks, significance and relationships on their jobs, thus attaching meanings to their work and building a work identity. This can be a hopeful research path, especially if we tackle the crafting process at the collective level, a direction pointed out by the authors as possible development of their original model. The job crafting model is presented in the next section.

We chose to examine this phenomenon in an interesting work context, namely among an information technology cluster. Information technology has introduced new possibilities of arranging work, thus representing possible changes to its meanings. As the physical workplace is replaced with virtual work that can be performed anywhere, traditional meaning-making processes are affected (Guevara \& Ord, 1996). For example, some status symbols, such as a corner office, and cultural values have to be reassessed. 
At the same time, boundaries between work and personal life become blurred as a work station is temporarily displaced to give room for family dinner. These characteristics render technology-driven arrangements promising fields in which to look for answers about the new meaning of work possibilities and, probably, the best place to see these new arrangements is the technological industry itself. Companies in this industry are usually described as innovative and experimentalist, not to mention that they are also becoming references for other businesses with regards to physical office layout, work arrangements, and team relationship. Investigating this type of environment could yield more insights about work arrangements, interpersonal relations and their linkages to the meaning-making process and work meanings.

With these problems and possibilities in mind, we designed a study to investigate the meanings of work and the meaning-making processes in the technology industry or, more specifically: 1 . To describe how workers of a technology cluster share meanings of work; 2 . To explore how these meanings and meaning-making processes relate to their work arrangements; and 3 . To explore how workers position themselves about the shared meanings and work arrangement.

\section{THE JOB CRAFTING MODEL}

We should find the roots of job crafting model on earlier studies integrating job design and meaning of work. Of particular interest to us are those studies concerned with the collective level of analysis - a level frequently unnoticed (Wrzesniewski et al., 2003). So, our starting point is Salancik and Pfeffer's (1978) social information processing framework connecting the meaning of work - in the form of task significance - and interpersonal behavior. They proposed that individuals use contextual information of their workplaces, such as cues and norms, to rationalize their decisions and guide their actions. It means that, instead of only relying on intrinsic needs and motivations, workers turn to what other people think to evaluate and adapt to the environment and to make sense of work. Shared beliefs, values, and motives direct their attention to certain aspects of the context instead of others. This framework was empirically validated (e.g., Schnake \& Dumler, 1987; White \& Mitchell, 1979) showing that social cues influence the perceived significance of a work task, especially when these cues are given by coworkers in the same hierarchical rank as the participant. 
Salancik and Pfeffer's (1978) framework was advanced by Wrzesniewski and Dutton (2001). By approaching the job design perspective (Hackman \& Oldhan, 1976), they developed the concept of job crafting recognizing the active role workers play in the process. Job crafting is a compound action comprising three types of changes made by workers in their jobs. First, changes in the physical task boundaries. Workers may choose to do less or more of the prescribed tasks (quantitative changes) and add or eliminate some activities (qualitative changes). Second, changes in cognitive tasks. Workers may choose how they see their work, regarding descriptions and evaluations of it. Third, changes in the relational boundaries. Workers may choose with whom they might interact and the degree of this interaction. Together, these changes affect both the meaning of work and one's work identity.

For Wrzesniewski et al. (2003), the meaning of work is also created and changed through perceived and interpreted behaviors, or cues, in the workplace. These cues may be intentional or non-intentional and could be something as subtle as a glance. Unusual and unexpected behaviors are more likely to be noticed and, because cues are actively interpreted, some of them can be ignored or disregarded. From this interpretation, workers may respond by reinforcing tasks, roles and behaviors that receive desired feedback and/or seeking to join and interact with groups that share their meanings or those meanings they want to reinforce.

Although Wrzesniewski and Dutton (2001) dealt only with individual level job crafting, they pointed to possible developments of the concept if examined at the collective level. Leana, Appelbaum, and Shevchuk (2009) were the first to address what they called collaborative job crafting. They found individual and collaborative job crafting are separate constructs, each one with their own sets of predictors and effects. Mattarelli and Tagliaventi (2012), then, proposed that individual job crafting supports collective job crafting. Tims, Bakker, Derks, and van Rhenen (2013) investigated how team job is crafting an improved individual performance. And Tims, Bakker, and Derks (2015) touched workers' subjectivity by investigating how individual job crafting may impact not only the job of colleagues but also their well-being.

What captures our attention in these studies regarding collective job crafting is their performance orientation (e.g., Leana et al., 2009; Luu, 2017; Mäkikangas, Aunola, Seppälä, \& Hakanen, 2016; Mattarelli \& Tagliaventi, 2012; Tims et al., 2013). Maybe, by concentrating on manageable antecedents of job crafting to foster it and increase performance (e.g., Mäkikangas, 
Bakker, \& Schaufeli, 2017), researchers are skipping the meaning of work dimension of the model.

Besides, these studies tend to use a collective job craft conception that emphasizes the deliberate aspect of workers' choices, implying that they "together decide, for example, which job resources they need to accomplish their tasks and together ensure that they mobilize these resources." (Tims et al., 2013, p. 432). But, as we should see ahead, at the meaning of work level, collective job crafting seems less deliberate and more emerging which does not counter the autonomous characteristic of job crafting.

Still, the theoretical advancements brought by the job crafting model represent a significant difference from former theories and imply different analytical categories and research possibilities. We reflect on the implications of our research for the job crafting model in the discussion section below.

\section{RESEARCH METHODS}

Starting from the connections between our objectives and the job crafting model, we designed basic qualitative research to investigate the contents and dynamics of the meanings attached to work by different players in a technology cluster. Basic qualitative research relies on interpretative analyses but does not require additional analytic dimensions (Merriam, 2016). That is, it is a non-differentiated qualitative research design, which 1 . Serves to verify a priori questions; 2 . Includes description, interpretation, and comprehension; 3. Identifies recurrent patterns (such as categories and themes); and 4. Uses existing theory (Mariz, Goulart, Régis, \& Dourado, 2005). This type of study naturally falls into the social constructionist paradigm (Merriam, 2016). For social constructionists, multiple realities - composed of meanings or interpretations - are created by social interactions inside specific cultural and historical contexts (Creswell, 2013). By integrating interpretation and interaction under the same outlook, this research design proved adequate for our research objectives.

Expecting coherent and complementary data to fuel fair comparisons, we chose to investigate people from different ranks, within an active and lively technology cluster named Porto Digital. This cluster is located in the northeast region of Brazil and, according to its institutional information, congregates more than 200 companies. From the cluster, we conveniently selected two average sized companies (i.e., companies in which the number of employees was approximate 34 , the cluster's mean). These companies 
were selected because they are typical examples of other companies in the cluster regarding their products (semi-customized software) and because, not being large "star" companies, they would exhibit less employee branding behaviors, for this would affect the meaning-making processes (Miles \& Mangold, 2004). From each company - and in line with our qualitative approach - we interviewed one owner, one manager and one worker (non-owner and non-manager). All of them volunteered for the research. The final sample was comprised of three men and three women, varying from 27 to 43 years old. We used a semi-structured script to guide the individual interviews which occurred in a neutral and informal place where informants could express themselves freely. We started to compose our interview script with questions regarding the three job crafting behaviors (i.e., physical task crafting; cognitive task crafting and relational job boundaries) but, as our main focus was the meaning of work component in the model, we arrived at a script with four topics: 1. Informants' subjective views about work; 2. Informants' working life history; 3 . Perceived interpersonal influences at work; and 4. Perceived relations between work arrangements and work meanings. The interviews took place in January of 2017 and yielded nearly 5 hours of audio data, transcribed by the researchers themselves for the analyses.

We, then, analyzed the data (transcribed texts) using content analysis to identify discourses, structures, patterns, meanings and contexts embedded in informants' answers (Bardin, 1998). A traditional content analysis was conducted. That is, data was pre-analyzed, explored and then interpreted. No software was used in this process, allowing deeper contact with the data. To assign codes and categories, we followed an inductive-deductive strategy. The first reading of the transcribed interviews induced insights that became codes and categories from which the data was then deductively analyzed.

The quotations substantiating this paper's findings and discussion were translated exclusively for this paper. Most colloquialisms, grammar errors, hesitations, and unintended word fragments were suppressed in these quotations, but not in the analysis. To provide clarity, the informants' hesitations we kept were represented with a simple ellipsis mark while our interpolations were represented by a bracketed ellipsis mark. In this article, informants' answers are quoted using the letter "P" (as in "person"), a numeric code (P1 through P6) and the hierarchical position they occupy (owner, manager or worker) to identify them. The analytic process was conducted entirely in the original language (Portuguese). For this research, only data grounded codes and categories were used. That is, they emerged 
from the data at the inductive step of our analyses. Our main analytic unit was the theme (thematic analysis), but we also considered the characteristics and evaluations assigned to these themes by the informants. These evaluations were especially considered when they varied among different informants.

Our analysis was informed and naturally aligned with the symbolic convergence theory (Mead, 1934), particularly with the concept of rhetorical vision (Bormann, 1972). Rhetorical visions are shared views dramatized by social groups. They have preferred ways of explaining, and therefore creating, the social reality. Through language and communication processes, groups create and share subjective worlds that symbolically mirror the social reality and reinforce attitudes and values using emotional engagement.

Although we have made some observations of the two companies (which were not used) and interviewed participants from different hierarchical levels, finding significant similarities between their responses/narratives, we did not achieve any kind of triangulation such as method, source, analyst or theory triangulation (Patton, 1999). Likewise, we stay on the conservative ground by recognizing one can argue about the representativeness of the sample - two companies and three informants in each company - even thought this is a disputed question on qualitative studies. We expect these limitations to be outweighed by the insights regarding the job crafting model, particularly its meaning of work dimension, tackled at the collective level by this inquiry. These insights are detailed in the discussion section.

\section{RESEARCH FINDINGS: A UNIFYING SAGA, FLEXIBLE WORK ARRANGEMENTS, AND THE ROLE-PLAYING}

Analogies and metaphors may enable and enrich the act of describing something (Morgan, 1980). In this article, we believe that a role-playing game metaphor permits a better presentation of our findings. This metaphor is already used in organizational research, and even the role-playing game itself has been considered useful as a management tool. The role-playing game metaphor was brought explicitly to the conversation by one of the informants while talking directly about the meaning of work. The informant compared the process of assigning meaning to work throughout an individual's lifetime to the increase of the XP bar (level of experience) of an individual's character or avatar supposedly performed at the workplace.

Role-playing games are interactive tales in which the players assume certain specific roles acted upon a shared backdrop narrative or a saga. The 
workers we interviewed at the technology cluster share meanings of work much like the role-playing game. Their saga, as in the game, provides a common ground and mutual objectives, thus connecting and engaging them both at the individual and collective levels. Their specific roles define expected behaviors, courses of action and development possibilities. Pairing a shared saga and distinct roles results in a well-structured environment, reducing doubts and uncertainties, while still granting much room for self-direction.

Both the saga and specific roles function as articulating points between the meaning of work and the work arrangements in the technology industry. Whenever possible, we present informants' quotes - sometimes multiple quotes on the same topic - to illustrate our findings and add context for discussion.

\subsection{The saga: reconciling meanings of work through work arrangements and fitting roles}

Our first examinations of the data pointed to the existence of a common theme in all informants' responses. They portrayed a common perception of work having two distinct meanings that must be balanced. On one hand, work is perceived as a way of earning money, implying independence from the parents and consumption opportunities. On the other hand, work is meant to fulfill other subjective aspirations not related to making money, such as self-development, aligning personal traits with job characteristics and doing something intrinsically satisfying.

[. . . work] is also very connected to a. . . how can I say. . . it is. . . like personal satisfaction, that is, you do what you like. At least most people try to follow that road of doing what they like. And I think it is [also] much related to survival, 'I need to work to get money,' and this association is very clear (P2 - Worker).

The instrumental meaning of work first appeared when informants talked about their parents' work experience. In fact, mentioning parents and grandparents were almost ubiquitous among informants when recounting their first thoughts and ideas about work. Most informants started from their parents' working history to articulate their own, usually around themes such as "working too much" or "working for the money." Their parents were, therefore, praised as examples of diligence and commitment, highlighting their pragmatic stances in response to rough circumstances or 
as a sign of character. Informants believe this is an attitude which should not be completely lost. An interesting topic for future research.

[. . .] I come from a family where work is valued. So my parents always had that. . . and mostly my father passed me that thing. . . he had been an entrepreneur forever, always had his business. My mother, I could hardly see because she worked too much, so. . . She was not very present at the school events, so, I think I always had this idea that I was going to be a person who worked a lot (P1 - Manager).

[...] my father and my mother always worked a lot and [we] saw each other only at night. And, at the time, since it was something very difficult, I pictured work as something tough, something tiresome. That was not cool; it was not something you did because you liked. And it was my child's view because I was always with my grandmother, at the time; my parents would come at night, tired, and had little time for themselves. So, my view was more on that side, that [work] was not a good thing (P2 - Worker).

This symbolic heritage may be the reason for informants' highlighting the economic dimension when talking about their first encounters with work. It was a social integration tool through consumption - in very much the way Tausky (1969) proposed - and also in the sense of independence and identity development.

[. . . ] at that time, I was very young, I already experimented some freedom to do stuff, buy things, take classes using that little compensation from those small jobs I did, and that pleased me a lot. So, for example, I paid some of my English classes with that, I bought my guitar with that - which was something I wanted so much at the time - I went places, concerts and this kind of things with that (P3 Owner).

And that is how it began, basically, at 14, 15 years old. I saw it [work] like this, like a path to independence because, from the moment I had my money to do whatever I wanted without asking anybody, it was like stating that. . . it was like saying 'this is my space. Up to this point, it will be my way and from here on it is another person's space'. And that is basically how it began (P2 - Worker). 
But, at some point in their journey, usually, when choosing a profession at the end of high school, they began to consider other subjective meanings. These two dimensions, though, do not compose a simplistic good versus a bad picture. Instead, they represent a complex, sometimes contradictory puzzle that employees seek to solve both individually and as a group.

And then I think it evolved with time, not only having one importance, like, my independence, but, as I said to you, it also leans toward satisfaction. Because everything I did was only to make money, so I did basically what they needed to help myself. And it came to the point that I had to think what I wanted to do, something that would get me paid, but that was also something that left me satisfied, made me happy (P2 - Worker).

Informants made it clear that how they felt society does not balance these two distinct meanings. Instead, objective economic concerns stifle the deeper subjective meanings of work. These deeper meanings need, therefore, to be found and cultivated again not only by the individual alone, but as a shared quest in which the organizations act as "opportunity fields" or, else, are deemed as "the wrong place to be." The aim is to build and engage in a work environment that recognizes the importance of balancing meanings and, therefore, provide certain conditions, such as flexibility and novelty, for them to flourish in. The technology industry itself is often cited as an example of this kind of environment, as opposed to factory-like work arrangements.

[. . .] I do not believe we are the majority. We are not the majority. Maybe, in the beginning, people embrace this vibe, but today, after so much, people see work simply as work, not fulfillment, work. [. . .] I think I'm working with a crowd that sees everybody more as co-workers and not employees, coworkers meant to grow up together. I believe many managers already have this view, but not the majority. [. . .] I feel, since I migrated to this technology area, I have found another feeling for this employer-employee relation (P1 - Manager).

Thus, it is the search for this ideal balance between the distinct meanings of work that constitutes the essence of the saga. Accounts of this search were frequent in informants' responses. "[. . .I was] searching for an arrangement that kept being purposeful, kept being fun, but that also brought the practical side, the practical dimension, that is related to work." (P3 - Owner). 
As we said before, the search acts as a binding quest in which all players engage and provides a common theme for them to interact in the workplace with regards to the meaning of work. And, since informants believe they can overcome society's narrow economic focus, both at the organizational level and at the interpersonal level, the quest is also assigned to organizations in the technology cluster. Solving the balance problem at the organizational level leads to the adoption of unorthodox work arrangements. Solving the balance problem at the interpersonal level is done through an adjustment to certain specific roles performed at work. These two effects are presented next.

\subsection{Offbeat work arrangements}

When it comes to working arrangements, there is a clear sense of movement forward, of shifting in history, among informants. They believe that, regarding workplace characteristics, the technology industry is different from other industries and also that they, as a group, are responsible for new ways of arranging work to suit people's aspirations.

[...] but I suppose that [working in a more traditional area] the work style, the work arrangement. . . it won't be something that would engage me, that would make me grasp how important work is, if I was in another area (P6 - Owner).

[...] at the other company I worked for, people. . . it was a company extremely. . . with an extremely outdated format. It had directors, bosses, managers and it was like a ladder indeed. [. . . I I think there is, maybe from part of the people working in the technology area. There is much more lightness than with people working in a factory. And not. . I I do not say. . . it is not even about taking work seriously, I don't know, not striving, not dedicating. I think it is more of lightness; I think this is mostly because of some companies' formats. Some companies' formats are very. . . like a small company's culture even being a large company. Like, everybody is friendly, everybody knows each other, everybody talks to each other, everybody has space and. . it is something that doesn't happen in a factory, for example. It is that ladder format that we were talking about before (P2 - Worker).

Flexibility is the most emphasized characteristic of work in the technology industry. It helps to change something without necessarily breaking or destroying it, thus becoming an important asset for crafting the workplace. 
[. . .] the greatest difference is this: basically, inside a technology company, you will have flexibility in virtually every organizational dimension, from the way you dress to the growth opportunities you get inside the company. Everything is way more flexible. I think this is the greatest difference ( $\mathrm{P} 3$ - Owner).

Flexibility, for our informants, usually manifest itself in a more loose and horizontal hierarchy. Workers want "transparency." They hope to understand where they are heading and why they must do something. This appears to be a direct response to the industrial fashioned labor division which sliced tasks in meaningless portions for each worker. Contrary to the classical Taylorist arrangement, where knowledge remained with the supervisor, in informants' horizontal conception, no organizational function is more important than any other. The underlined aim of the saga - and the resulting arrangements - is a kind of "harmony." Rebuilding the lost "whole" of work and recovering workers interrelations in mutual understanding or, in informants' words, "aligning expectations."

[...] I think it has a lot to do with expectations too. The bigger the difference, like, between ranks, let's put it this way, the easier for you to develop different expectations. [. . .] I think communication, transparency is very important now. [. . .] I don't know if anybody would accept to be in a situation where you don't know what's happening around you, it's complicated (P2 - Worker).

\subsection{The roles: apprentices and tutors}

Informants of all ranks spoke about the need to match one's personality traits with the job and the organization's characteristics. This occurs by adhering to an accepted role which functions as a password to fit into the group, to legitimate their position in the technology industry, and also to explain why some individuals do not adapt to a specific organization or the type of work arrangement found in technology. That could be, in fact, a failure to assimilate the roles and engage in the saga. This conformity failure can eventually lead to insincere behaviors or, maybe, unauthorized pretending.

These are the guys that manage to deceive themselves and to deceive others. So they are self-deceiving because, at this moment, they are 
trying to say that this environment is their intended environment, but it is not. These are the guys who misrepresent. [. . .] There are people like this, even in this environment. In a lesser proportion, I believe, than in other environments because the interpersonal relations are closer and everybody addresses the meaning of being here the same way (P6 - Owner).

The roles available for players to pick up while performing the saga are structured around the notions of learning and tutoring (or teaching). This structure probably results from the self-knowledge and self-development meanings of work, emphasized in the saga and from the nature of the technology area, one that is culturally related to novelty and discovery, and one that informants are ready to engage with as apprentices. Work is portrayed as a vehicle for a self-development journey, in which infantile perspectives are replaced with more mature and, overall, balanced views. This may naturally lead to the adoption of a set of roles comprising "apprentices" and "tutors." Very often, informants - from all hierarchical levels - put themselves explicitly in the apprentice seat. They continuously used expressions such as "learning," "maturing," "developing," "knowing," "improving" and "evolving."

I think work is a space for self-knowledge and self-development which, without work, you. . . it takes longer, I think, to evolve in certain questions related to yourself, knowing yourself, your potentials, talents and also your shortcomings in general [...] I emphasize this first dimension because it is for this reason that work has huge importance in people's lives (P3 - Owner).

I think [in organizations] there is too much, very much indeed, lack of know-how. And by know-how, I don't mean holding a degree, because I think this doesn't mean much. I think it is more the personal interest about what you are doing, you seeking improvement; this is what I miss most today, especially on those beginning (P3 - Owner).

Work. . . I think it is the act of building something, of developing, of. ... maybe because of my workplace today, I don't see work as an obligation. Waking up and saying 'I'm going to work.' I think it's more in the sense of 'today I'm going to learn something new, today I will develop such a thing.' For me, it's something pleasant. (P5 Manager). 
Newcomers are often regarded as naïve or "daydreamers," focusing more on the subjective fulfillment to be found in work. Thus, they need to be guided and enlightened about the dual meaning of work to also consider the objective aspects of work, including "working hard," and pursuing the desired balance. This creates the foundation for the apprentice-tutor role structure. This particular finding highlights the dual nature of the meaning of work as constructed by the participants: not only economic reasons, nor only personal fulfillment.

I believe that this group is arriving now. . . more than it was. . . then those who arrived with me, they do not realize what work really is. They do not, you know? I think they do not hold on. I think they lack the understanding that you need to really fight a lot to get anything (P1 - Manager).

We found it particularly interesting that the hierarchical relationship was mirrored in the learning-teaching relationship. That is, although all informants, regardless their hierarchical level, talked about learning, only owners took the role of teaching. So, the subordinate-superior relationship corresponds with the apprentice-tutor roles. In the words of a company owner "so it [what he expected from work] is. . . to be able to connect to people, find them interesting, having an interesting exchange, be able to learn, be able to teach something also [...]" (P3 - Owner). Conversely, the words of an employee state:

So my relationship [with superiors] is always about learning [. . . ] I very much put myself in the apprentice position still, and I think I still have much to evolve. And it is good on one side; it denotes humbleness. (P1 - Manager).

While this correspondence between the interpreted roles within the saga and the concrete hierarchical positions outside the saga may result simply from the fact that bosses are responsible for their teams, we believe it also provides for further discussion, especially in the practical developments of our findings.

\section{DISCUSSION: PRACTICAL AND THEORETICAL IMPLICATIONS OF THE SAGA AND THE ROLES}

Having uncovered some shared meanings of work and also the mechanisms used in the meaning-making process in the studied technology 
companies, we may now turn to some theoretical implications of our findings to the job crafting model and also to a discussion on the practical developments for workers.

\subsection{The meaning of work saga and the job crafting model}

With their job crafting model, Wrzesniewski and Dutton (2001) managed to combine the physical, psychological and social aspects of work and subjectivity. They also considered the relations between the task, the meaning of work and the work identity. Their model beautifully integrates various research threads as well as reintroduces classic topics such as the loss of an overall picture and the relationship between work and identity. Job crafting is also an empowering theoretical framework not only because of the autonomy it can provide if acted upon, but first and mainly because it portrays the workers as active players even under unfavorable scenarios such as low autonomy jobs.

From the model proposed by Wrzesniewski and Dutton (2001), our research found all three of the different types of job crafting. Physical job crafting is present in informants' deliberate attempts to develop work arrangements that are compatible with their aspirations. Some of those aspirations are indeed closely related to their physical task. The desire for task independence and wholeness in task division are two examples of that. Cognitive crafting is achieved through the saga itself. The narrative provides a comprehensive backdrop used to frame and give meaning to informants' work.

Interestingly, the saga is a recursive narrative, since informants define the meaning of their work as searching for meaningful work. Relational crafting is found in the usage of definite roles to mediate relationships at work with obvious impacts on work identity. At the method level, we also found Wrzesniewski and Dutton's (2001, pp. 196-197) advice concerning the use of narratives in studying job crafting as particularly helpful.

Our tale would be a prototypical job crafting example except, unlike the original examples illustrating the model, it occurs at the collective level. We already commented that by collective level we do not mean hierarchically, formal organizational level and that this path may lead to unintended results. At this point, we think it is important to draw attention to the fact that the collective dimension we explored differs from other collective job crafting studies. Taking on a more instrumental approach, these studies tend to focus strictly on the changes made to the tasks (e.g. Bizzi, 2017; Leana et al., 
2009; Matterelli \& Tagliaventi, 2012; Tims et al., 2013), not focusing on the evaluative perceptions of the worker and the meaning-making processes. In other words, these studies are concerned more with the job design embedded in job crafting than with the meaning of work aspect of it.

In a different direction, we found that, at this collective level, the meaning of work is even more central to the job crafting model than when it is observed at the individual level. From our data, it is the meaning of work - and not the task - that seems to be the pivotal point, and collectiveness appears in the process of attaching meaning to work through a shared narrative. Our choice in using the words work and worker, instead of Wrzesniewski and Dutton's (2001) expressions such as task, job, and employee is meant to signal this last point.

\subsection{Practical developments and implications}

Our informants' narrative conveys a sense of transition, of a process, rejecting a static vision that characterizes more stable times. It can be a hint that, at some level, they position their saga - and, therefore, their objectives - within a broader historical time frame. We feel, though, that their references are somewhat limited and that this can bring some difficulties in their attempts to improve work meaningfulness. Their references are composed, on the one hand, by a familiar representation of the Taylorist and bureaucratic work arrangements and, on the other hand, by close family and personal experiences. In other words, they cannot see how their saga fits into the larger history of work and workers.

That is not to say they have such an obligation of knowing this history and fight this or that specific battle. Nor does it mean they are not attempting an important step, which they are. But, being unaware of the previous stages and recent developments of working life does not come without consequences. While considering the Taylorist industrial work arrangements and the homo economicus "the oldest [working concepts] possible" (P1), they ignore that they are reenacting the pre-Taylorist arrangement in many ways. For example, the learner role as a fitting mechanism into work was already an institutional mechanism in the Taylorist model and even before in the pre-industrial guilds. Also from this pre-Taylorist period is the division of tasks in a way that external dependence is minimized and, therefore, more autonomy is granted.

An excessively dichotomized view on the present-past may also lead them to believe that only now workers are looking for better conditions 
and meaningful work. It disregards the many stages in workers' demands, first for survival, then for better working conditions and finally for better life conditions (Dejours, 1992). Our informants' views echo an apparent emergence of a leisure culture (Quintanilla \& Wilpert, 1991; Vecchio, 1980), which is also very narrowly situated in the opposition of pre and post-World War II social values. This localized perspective is also manifested when informants portray their struggles for overcoming difficulties seen in the immediate context of their families (parents and grandparents). This family history creates a specific identity locus and bounds it to the individual level instead of a broader worker identity. The saga is a compound of specific stories, in a very post-modern fashion, rather than a larger historical movement.

At the work arrangements level, the saga is staged as an attempt to solve the problem of meaning in Taylorist industrial work by introducing "flexibility" in the work arrangement. But flexible work arrangements are not exactly new and also have their own particular problems such as blurred boundaries between free and work time and subjective ideological manipulation, for example. Even in the flexible era, there is still a lack of autonomy and management-worker separation. For instance, increasing communication between hierarchical levels - one of our informants' demands - appears to be a logical answer to the well-known lack of an overarching vision and meaninglessness resulting from excessive task division. But increasing communication may only go so far in providing reasoning for work intensification and impart a sense of being considered without effectively touching the real problem. For example, opening these communication paths presupposes some horizontality in the work relations. This leveling is shown by the fact that all informants explicitly said they did not see any function more important than any other function, inside organizations. But this does not explain (again, from their own words) why people are paid differently. We believe that solving the meaning of work problems is not possible by ignoring that kind of structural problem.

While we see the apprentice-tutor role system as smoothing a more rigid hierarchical relation, we also found a traditional, hierarchical accent in the fact that only bosses adhered to the tutor role. This does not mean necessarily a manipulative domination, but it is a point worth mentioning. Collective job crafting inside hierarchical relationships is a contradictory concept since, by definition, job crafting occurs by tweaking the boundaries of the formal (hierarchically defined) job description. Turning job crafting into a managed practice, with all or most of its processes controlled by 
managers seeking only to enhance workers' performance and retention, may be a potential trapdoor. It would mean to capture workers' autonomy and put it back in the circuit of traditional hierarchical job design.

Also, we believe that the meaning-making processes found in our research allow for some interesting inferences and future research paths. First, the similarities between owners', managers' and workers' views and, also, the contents of their speeches show no traces of the exploitation theme. We see this as a possible result of the informants' demographics. All of them, including the owners, come from similar socioeconomic backgrounds and, therefore, hold similar references. Also, the owners of this medium to small tech companies do not resemble the capitalist stereotype. Instead, they seem to think and behave just like their subordinates and some of these owners were employees not so many years ago. So, they all share the same concerns regarding work. This could help explain why we found no deification of the organization, or the organizational man, faithful to its new religion (Pagès, Gaulejac, Bonetti, \& Descendre, 1998).

Nonetheless, only the owners' narratives presented the connection and the balance between subjective and objective aspects of work. For the other informants, this balance was still a distant goal. Maybe future studies could further investigate these similarities and differences and find possible paths to better integrate workers, managers and, owners.

\section{FINAL CONSIDERATIONS}

This article aimed to examine meaning-making processes in the technology industry. We found that people working in the technology field clearly insulate themselves from the traditional industrial, factory-like, type of work. In fact, they describe their stance as having different meanings attached to work and building an environment where they can exert this view. It is a shared quest that unites them and makes them a selected group.

To complete this quest, they build flexible organizations and fit themselves into identifiable roles. They value the pre-Taylorist kind of work arrangement one that allows workers to trace their work all the way up to what it means to the final product and how it can contribute to others. A work that also does not mean splitting individuals along the task chain. The role structure also contributes to this affiliating and cohesive atmosphere. Although roles are conformity rails, informants seemed to impart a sense of fairness to this settlement. Even when they talked about the dissonant, 
those who did not fit the accepted roles, they expressed it regarding selfdeception, as if the outsider could not overcome the distorted meanings inculcated by society.

Attaching meaning to work in the form of a saga, of historical progress, indicates informants are aware of a transition. They portray a changing process and not a static vision, characteristic of a hegemonic period. They incarnate an active role in shaping their meanings for work and work identities and materialize it in their work arrangements. With their collective narrative, they become testimonies of Frankl's (2006) will to meaning.

Theoretically speaking, we believe that our research shows that, although Wrzesniewski and Dutton (2001) located job crafting at the job level, it may be a useful concept to further meaning of work research. Maybe people are bound to talk about their tasks and jobs because it is the concrete instance of work for them, the only way they can grasp this matter.

The saga is not finished. It is bounded to destinations that are very fond of anyone who has experienced work. It points to harmony through horizontal organizations and transparency, to a mutual understanding and, hopefully, the rebuilding of the whole of work through the reintegration of workers. Maybe, despite all the possible drawbacks in their saga, the apprentices in the technology industry can teach us a lesson with their attempts to balance diverse meanings of work.

\section{ACKNOWLEDGMENTS}

We sincerely thank Andrea Leite Rodrigues for her encouragement on the presentation of the first version of this article at the 2017 edition of EnGPR (Encontro de Gestão de Pessoas e Relações de Trabalho). We also thank Kate Horton for her valuable comments on earlier versions of this article.

\section{A SAGA DO SIGNIFICADO DO TRABALHO: UMA EXPERIÊNCIA DE JOB CRAFTING COLETIVO}

\section{RESUMO}

Objetivo: Nosso objetivo principal foi explorar como o job crafting coletivo se relaciona com o significado do trabalho e com o processo de construção desse significado. 
Originalidade/valor: Nós exploramos o modelo de job crafting para estudar o significado do trabalho no nível coletivo. Porém, enquanto a maioria dos estudos sobre job crafting se concentra na relação entre os trabalhadores e as tarefas, nós focalizamos a construção coletiva de significado que emerge quando os trabalhadores alteram ativamente as tarefas, sua significância e seus relacionamentos no trabalho. Quanto aos profissionais, nós alertamos para a possível armadilha através da qual o job crafting pode ser reduzido a um simples job design hierarquizado, caso não ocorra de forma ativa e autônoma pelos trabalhadores.

Design/metodologia/abordagem: Nós usamos um estudo qualitativo básico para combinar análise interpretativa (alinhada ao tópico de estudo e modelo teórico escolhido) e a possibilidade de examinar um cenário de interação (alinhado aos nossos objetivos). Os dados foram coletados através das respostas dos informantes a uma entrevista semi-estruturada e analisados usando a técnica de análise de conteúdo.

Resultados: Nós verificamos que os trabalhadores compartilham um entendimento sobre os problemas com os significados do trabalho e se engajam em uma missão para dar sentido às suas vidas profissionais tanto 1. No nível organizacional - arranjando o trabalho de maneiras não ortodoxas; e 2. No nível interpessoal - aderindo a papeis específicos para dar significado ao trabalho. Nossos achados lançam luz sobre novos aspectos do modelo de job crafting, particularmente sobre a centralidade do trabalho no modelo quando se trata de experiências de job crafting coletivo.

\section{PALAVRAS-CHAVES}

Significado do trabalho. Trabalho com sentido. Gerenciamento do significado. Job crafting coletivo.

\section{REFERENCES}

Antunes, R. (2009). Os sentidos do trabalho: Ensaio sobre a afirmação e a negação do trabalho [The meaning of work: Essay on the affirmation and the denial of work]. São Paulo, SP: Boitempo. 
Bardin, L. (1998). L'Analyse de contenu [Content analysis]. Paris, FR: Presses Universitaires de France.

Bailey, C., Madden, A., Alfes, K., Shantz, A., \& Soane, E. (2017). The mismanaged soul: Existential labor and the erosion of meaningful work. Human Resource Management Review, 27(3), 416-430. doi:10.1016/j.hrmr. 2016.11.001

Bizzi, L. (2017). Network characteristics: When an individual's job crafting depends on the jobs of others. Human Relations, 70(4), 436-460. doi:10. 1177/0018726716658963

Bormann, E. G. (1972). Fantasy and rhetorical vision: The rhetorical criticism of social reality. Quarterly Journal of Speech, 58, 396-407. doi:10.1080/ 00335637209383138

Braverman, H. (1998). Labor and monopoly capital: The degradation of work in the twentieth century. New York, NY: Monthly Review Press.

Busse, R., Kwon, S, Kloep, H., Ghosh, K., \& Warner, M. (2018). Toward a "meaningful self" at the workplace: Multinational evidence from Asia, Europe, and North America. Journal of Leadership \& Organizational Studies, 25(1), 63-75. doi:10.1177/1548051817709009Cartwright, S., \& Holmes, N. (2006). The meaning of work: The challenge of regaining employee engagement and reducing cynicism. Human Resource Management Review, 16(2), 199-208. doi:10.1016/j.hrmr.2006.03.012

Cleavenger, D., \& Munyon, T. (2013). It's how you frame it: Transformational leadership and the meaning of work. Business Horizons, 56 (3), 351-360. doi:10.1016/j.bushor.2013.01.002

Creswell, J. W. (2013). Qualitative inquiry and research desing: Choosing among five approaches. Thousand Oaks, CA: Sage.

Dejours, C. (1992). A loucura do trabalho: Estudo de psicopatologia do trabalho. São Paulo, SP: Cortez-Oboré.

Frankl, V. (2006). Man's search for meaning. Boston, MA: Beacon Press.

Guevara, K., \& Ord, J. (1996). The search for meaning in a changing work context. Futures, 28(8), 709-722. doi:10.1016/0016-3287(96)00030-4

Hackman, J. R., \& Oldham, G. (1976). Motivation through the design of work: Test of a theory. Organizational Behavior and Human Performance, 16, 250-279. doi:10.1016/0030-5073(76)90016-7

Kochan, T. (2016). Shaping the future of work: What future worker, business, government and education leaders need to do for all to prosper. New York, NY: Business Expert Press. 
Leana, C., Appelbaum, E., \& Shevchuk, I. (2009). Work process and quality of care in early childhood education: The role of job crafting. Academy of Management Journal, 52(6), 1169-1192. doi:10.5465/AMJ.2009.47084651

Lips-Wiersma, M., \& Morris, L. (2009). Discriminating between 'meaningful work' and the 'management of meaning'. Journal of Business Ethics, 88(3), 491-511. doi:10.1007/s10551-009-0118-9

Luu, T. T. (2017). Collective job crafting and team service recovery performance: A moderated mediation mechanism. Marketing Intelligence and Planning, 35(5), 641-656. doi:10.1108/MIP-02-2017-0025

Mäkikangas, A., Aunola, K., Seppälä, P., \& Hakanen, J. (2016). Work engagement-team performance relationship: Shared job crafting as a moderator. Journal of Occupational and Organizational Psychology, 89(4), 772-790. doi:10.1111/joop.12154

Mäkikangas, A., Bakker, A. B., \& Schaufeli, W. B. (2017). Antecedents of daily team job crafting. European Journal of Work and Organizational Psychology, 26(3), 421-433. doi:10.1080/1359432X.2017.1289920

Mariz, L. A., Goulart, S., Régis, H. P., \& Dourado, D. (2005). O reinado dos estudos de caso na teoria das organizações: Imprecisões e alternativas [The reign of case study in organizational theory: imprecisions and alternatives]. Cadernos EBAPE.BR, 3(2), 1-14. doi:10.1590/S1679-395 12005000200005

Matterelli, E., \& Tagliaventi, R. (2012). How offshore professionals' job dissatisfaction can promote further offshoring: Organizational outcomes of job crafting. Journal of Management Studies, 52 (5), 585-620. doi:10.1111/j. 1467-6486.2012.01088.x

Mead, G. (1934). Mind, self and society: From the standpoint of a social behaviorist. Chicago, IL: The University of Chicago Press.

Merriam, S. B. (2016). Qualitative research: A Guide to design and implementation. San Francisco, CA: Jossey-Bass.

Miles, S. J., \& Mangold, G. (2004). A conceptualization of the employee branding process. Journal of Relationship Marketing, 3(2-3), 65-87. doi:10.13 00/J366v03n02_05

Morgan, G. (1980). Paradigms, metaphors, and puzzle solving in organization theory. Administrative Science Quarterly, 25(4), 605-622. doi:10.2307/ 2392283

Pagès, M., Gaulejac, V., Bonetti, M., \& Descendre, D. (1998). L'Emprise de l'organisation [The hold of organizations]. Paris, FR: Desclée de Brouwer. 
Patton, M. Q. (1999). Enhancing the quality and credibility of qualitative analysis. Health services research, 34(5/2), 1189-1208. Retrieved from: https://www.ncbi.nlm.nih.gov/pubmed/10591279/

Quintanilla, S. A., \& Wilpert, B. (1991). Are work meanings changing? European Work and Organizational Psychologist, 1 (2-3), 91-109. doi:10.1080/ 09602009108408515

Rodrigues, A. L., Morin, E., \& Strehlau, S. (2009). A imagem de executivos na mídia: Um estudo com jornais de Québec [The image of executives in media: studying Québec newspapers]. Cadernos EBAPE.BR, 7(2), 232-251. doi:10.1590/S1679-39512009000200005

Salancik, G. R., \& Pfeffer, J. (1978). A social information processing approach to job attitudes and task design. Administrative Science Quarterly, 23(2), 224-253. doi:10.2307/2392563

Schnake, M. E., \& Dumler, M. P. (1987). The social processing model of task design: Conflicting cues and individual differences. Group \& Organization Studies, 12(2), 221-240. doi:10.1177/105960118701200208

Tausky, C. (1969) Meanings of work among blue-collar men. The Pacific Sociological Review, 12 (1), 49-55. doi:10.2307/1388214

Tims, M., Bakker, A. B., Derks, D., \& Rhenen, W. (2013). Job crafting at the team and individual level: Implications for work engagement and performance. Group \& Organization Management, 38(4), 327-354. doi:10.1177/1059601113492421

Tims, M., Bakker, A. B., \& Derks, D. (2015). Examining job crafting from an interpersonal perspective: Is employee job crafting related to the well-being of colleagues? Applied Psychology, 64(4), 727-753. doi:10.1111/ apps. 12043

Vecchio, R. P. (1980). The function and meaning of work and the job: Morse and Weiss (1955) revisited. Academy of Management Journal, 23(2), 361367. doi:10.5465/255439

White, S., \& Mitchell, T. (1979). Job enrichment versus social cues: A comparison and competitive test. Journal of Applied Psychology, 64(1), 1-9. doi:10.1037/0021-9010.64.1.1

Wrzesniewski, A., \& Dutton, J. (2001). Crafting a job: Revisioning employees as active crafters of their work. Academy of Management Review, 26(2), 179201. doi:10.5465/AMR.2001.4378011

Wrzesniewski, A., Dutton, J., \& Debebe, G. (2003). Interpersonal sensemaking and the meaning of work. Research in Organizational Behavior, 25, 93-135. doi:10.1016/S0191-3085(03)25003-6 


\section{J Wurtoren}

Newton C. M. de Melo, Centro de Ciências Sociais Aplicadas, Universidade Federal de Pernambuco (UFPE); and Débora C. P. Dourado, Centro de Ciências Sociais Aplicadas, Universidade Federal de Pernambuco (UFPE).

Newton C. M. de Melo is now Master's student at Centro de Ciências Sociais Aplicadas at Universidade Federal de Pernambuco (UFPE); and Débora C. P. Dourado is now Professor at Centro de Ciências Sociais Aplicadas at Universidade Federal de Pernambuco (UFPE).

Correspondence concerning this article should be addressed to Newton C. M. de Melo, Avenida dos Economistas, S/N, Cidade Universitária, Recife, Pernambuco, Brazil, CEP: 50.670-901.

E-mail: newtonclaizoni@gmail.com

\section{EDITORIAL BOARD}

\section{Editor-in-chief}

Silvio Popadiuk

Associated Editor

Andrea Rodrigues

Technical Support

Vitória Batista Santos Silva

\section{EDITORIAL PRODUCTION}

Publishing Coordination

Irina Migliari

Editorial Trainee

Maria Luiza Vanz

Copy Editor

Irina Migliari
Language Editor

Daniel Leão

Layout Designer

Emap

Graphic Designer

Libro 